\title{
Further processing characteristics of breast and leg meat from fast-, medium- and slow-growing commercial chickens
}

\author{
Cécile BERRI ${ }^{\mathrm{a} *}$, Elisabeth LE BIHAN-DUVAL ${ }^{\mathrm{a}}$, Elisabeth BAÉZA ${ }^{\mathrm{a}}$, \\ Pascal CHARTRIN ${ }^{\mathrm{a}}$, Laurent PICGIRARD ${ }^{\mathrm{b}}$, Nathalie JEHL $^{\mathrm{c}}$, \\ Maxime QUENTIN ${ }^{\mathrm{a}}$, Michel PICARD ${ }^{\mathrm{a}}$, Michel Jacques DUCLOS ${ }^{\mathrm{a}}$
${ }^{a}$ Station de Recherches Avicoles, Institut National de la Recherche Agronomique, 37380 Nouzilly, France
b Association pour le Développement des Industries de la Viande, 2 rue Chappe, 63039 Clermont-Ferrand Cedex 2, France
${ }^{\mathrm{c}}$ Institut Technique de l'Aviculture, 28 rue du Rocher, 75008 Paris, France

(Received 10 June 2004; accepted 1 February 2005)

\begin{abstract}
Standard fast-growing (FG), 'label' slow-growing (SG), and medium growing (MG) chicken crosses were grown until their market ages: 6,8 and 12 weeks, respectively. They were compared for carcass and muscle traits and meat processing ability. The breasts of 6wk-FG birds contained less protein, more fat and muscle fibres with larger diameters than those of $8 \mathrm{wk}-\mathrm{MG}$ and $12 \mathrm{wk}-$ SG birds. The $\mathrm{pH}_{15}$ and $\mathrm{pH}_{\mathrm{u}}$ values of breast and thigh muscle were the highest in the $6 \mathrm{wk}-\mathrm{FG}$ and the lowest in the 12wk-SG. The latter exhibited higher breast drip loss compared with the $6 \mathrm{wk}-\mathrm{FG}$. During processing, the highest curing-cooking yields were obtained with the breast and leg meat from 6wk-FG and the lowest with that from the 12wk-SG. As a consequence of their reduced water holding ability, the processed meat from the $12 \mathrm{wk}-\mathrm{SG}$ exhibited the lowest moisture and the white curedcooked meat showed the driest texture and the best slice cohesiveness. This study suggests that processing ability and processed product characteristics of breast and leg meats are greatly related to the chicken type of production, with fast growing birds being more adapted to further processing than slow growing ones in terms of profitability.
\end{abstract}

chicken / strain cross / meat / curing-cooking

Résumé - Qualité technologique de la viande de filet et de cuisse de poulets commerciaux à croissance rapide, intermédiaire ou lente. Des poulets issus d'une souche standard à croissance rapide (FG), d'une souche 'label' à croissance lente (SG), et d'un croisement à croissance intermédiaire (MG) ont été élevés jusqu’à leurs âges respectifs de commercialisation : 6 semaines pour les FG, 8 pour les MG et 12 pour les SG. Nous avons comparé leurs caractéristiques musculaires et la qualité technologique de leurs viandes. Les filets des poulets standards (FG) contenaient moins de protéines, plus de lipides et présentaient des fibres musculaires de diamètre plus large que les

* Corresponding author: berri@tours.inra.fr 
deux autres types de poulets (MG et SG). Les pH à 15 minutes et à $24 \mathrm{~h}$ post mortem des muscles du filet et de la cuisse étaient les plus élevés chez les animaux standards (FG) et les plus faibles chez les animaux de type 'label' (SG). Les filets de ces derniers présentaient par ailleurs des pertes par exsudation supérieures à celles des filets des poulets standards. Lors de la transformation par saumurage-cuisson, les rendements technologiques les plus élevés ont été obtenus pour la viande de filet et de cuisse des poulets standards et les rendements les plus faibles pour la viande des poulets de type label. Du fait de leur pertes en eau supérieures lors de la transformation par saumuragecuisson, les produits élaborés à base de viande de poulets labels présentaient les teneurs en eau les plus faibles, et dans le cas des blancs de poulets, la texture en bouche la plus sèche et la meilleure tenue de tranche. Cette étude montre que l'aptitude à la transformation ainsi que la qualité des produits élaborés sont largement influencées par le type de poulet, la viande des poulets de type standard paraissant la plus adaptée, d'un point de vue économique, aux procédés de transformation par saumurage-cuisson.

\section{poulet / croisement génétique / viande / saumurage-cuisson}

Abbreviation key: $a^{*}=$ redness; $b^{*}=$ yellowness; CSA = cross sectional area; $F G=$ fast growing; $\mathrm{IT}=$ Ilio tibialis; $\mathrm{L}^{*}=$ lightness; $\mathrm{MG}=$ medium growing; $\mathrm{PCL}=$ protein free of collagen and lipid; $\mathrm{pH}_{15}=15$ min post mortem muscle $\mathrm{pH} ; \mathrm{pH}_{\mathrm{u}}=24$ h post mortem muscle $\mathrm{pH} ; \mathrm{PM}=$ Pectoralis major; $\mathrm{SG}=$ slow growing.

\section{INTRODUCTION}

In France, the broiler meat industry has developed extensive methods of production to answer to consumer demands for enhanced animal welfare and more tasty products [29]. The two major alternative production systems are slow-growing 'label'- and medium-growing 'certified'-type chickens which are reared with lower stocking density and fed with lower energy and a higher cereal diet than are standard broilers. For label production, the birds also have access to an outdoor area after 6 weeks of age. Certified- and label-type chickens are respectively slaughtered around 8 and 12 weeks of age. Both of these production systems adopt chicken strain crosses with growth performance and body composition well-adapted to the carcass shape and the sensorial meat quality expected by consumers. Generally, meat from label chickens is judged firmer and less juicy but more flavoursome than meat from standard birds [7]. According to Farmer et al. [9], sensory differences between label and more intensively reared chickens may be explained by a combined effect of genotype, slaughter age, diet and stocking density.
Currently, label chickens (29\% of French consumption) are mainly sold as whole carcasses $(82 \%)$ whereas certified birds $(10 \%$ of French consumption) are also used for the cut-up market $(60 \%)$ [20]. The market of the further processed meat products is rapidly developing in France $(+5 \%$ per year). At present, standard broilers are mainly used but the processed product market could also be a future opening for label and certified chicken production. Data are currently not available regarding the functionality of meat from these two types of chickens. In the broiler, the first results tend to show that selection for rapid growth and muscle development can produce meat with a slower $\mathrm{pH}$ decline, higher ultimate $\mathrm{pH}$ and consequently lower drip loss [6, 18] and therefore it affects the processing quality of meat. Indeed, it is well known that the onset and the extent of post mortem muscle acidification can strongly influence functional properties of poultry meat $[2,10,24,25]$.

In the present experiment, we investigated the variability of muscle characteristics in relation with the curing-cooking yield and the further processing quality of meat from slow-, medium- and fast-growing chickens slaughtered at market ages. 


\section{MATERIALS AND METHODS}

\subsection{Birds}

Male broilers from fast- (FG), medium(MG) and slow-growing (SG) commercial crosses, supplied by Hubbard-ISA, were reared in a conventional poultry house at the Station de Recherches Avicoles (Nouzilly, France). Animals of each genotype were randomly distributed into 8 blocks in the poultry shed $(3$ genotypes $\times 8$ replicates $=$ 24 floor pens $\left(3 \mathrm{~m}^{2}\right)$ of 30 to 47 chickens). The stocking density was 15.7 birds per $\mathrm{m}^{2}$ for FG and 10 birds per $\mathrm{m}^{2}$ for MG and SG. Diet compositions are fully described in Table I.

A sample of 80 birds from each strain cross (10 birds $\times 8$ floor pens) was slaughtered at the age of 6 weeks for the FG cross (6wk-FG), 8 weeks for the MG cross ( 8 wkMG) and 12-weeks for the SG cross (12wkSG) in the experimental processing plant of the Station de Recherches Avicoles. After 8-h feed withdrawal per litter, the broilers were electrically stunned in a water bath before bleeding by ventral neck cutting. After scalding $\left(51^{\circ} \mathrm{C} ; 3 \mathrm{~min}\right)$, plucking and manual gut removal, whole carcasses were air chilled in a cold room at $2{ }^{\circ} \mathrm{C}$ for $24 \mathrm{~h}$.

\subsection{Muscle chemical and histological analyses}

Samples from the left Pectoralis major (PM) muscle of 16 birds of each strain cross (6wk-FG, 8wk-MG and 12wk-SG) were collected within 5 min post mortem and stored for chemical composition and histological analyses. The samples for histological analyses were rapidly frozen in isopentane cooled with liquid nitrogen then stored at $-80{ }^{\circ} \mathrm{C}$, while the samples to be analysed chemically were stored at $-20{ }^{\circ} \mathrm{C}$. Protein content was determined on duplicate $2-\mathrm{g}$ samples [3]; dry matter content from duplicate 5 -g of mince dried for $24 \mathrm{~h}$ at $105^{\circ} \mathrm{C}$ and lipid content according to Folch et al. [12]. The mean cross sectional area (CSA) of muscle fibres was determined as described by Rémignon et al. [26].

\section{3. pH measurements}

The remaining 64 chickens per group (6wk-FG, 8wk-MG and 12wk-SG) were used to determine the $\mathrm{pH}$ of the left Pectoralis major (PM) and Ilio tibialis (IT) muscles at $15 \mathrm{~min}$ and $24 \mathrm{~h}$ post mortem using a portable pH-meter (Model 506, Crison Instruments, SA, Spain) equipped with a xerolyte electrode. At 15 min post mortem, $\mathrm{pH}$ was estimated from $2 \mathrm{~g}$ of muscle mixed in $18 \mathrm{~mL}$ of a $5 \mathrm{mM}$ iodoacetate solution. This method was described as a reference method by Santé and Fernandez [28]. At $24 \mathrm{~h}$ post mortem, the ultimate meat $\mathrm{pH}$ $\left(\mathrm{pH}_{\mathrm{u}}\right)$ was recorded by direct insertion of the xerolyte electrode in the left PM and IT muscles. This method was adopted because of the significant correlation obtained $24 \mathrm{~h}$ post mortem between the direct tissue measurement of $\mathrm{pH}$ and the reference "iodoacetate" method [28].

\subsection{Growth and body conformation}

At $24 \mathrm{~h}$ post mortem, the breast muscles (Pectoralis major and minor), leg (thigh + drumstick), and abdominal fat ( $\mathrm{n}=64)$ were collected, weighed and yields were calculated in relation to body weight. Skin was removed from the breast but was left on the leg. The right breast (only PM muscle) and leg $(n=64)$ were vacuum-packed and stored at $-20{ }^{\circ} \mathrm{C}$ until processing.

\subsection{Drip loss and colour}

At $24 \mathrm{~h}$ post mortem all the left PM muscles and legs $(n=64)$ were weighed then placed in polyethylene bags and stored at $4{ }^{\circ} \mathrm{C}$ for 2 days. At $72 \mathrm{~h}$ post mortem the PM muscles and legs were removed from the bags, wiped and weighed to evaluate drip loss expressed as the percentage of the initial weight. At this time, $\mathrm{L}^{*}, \mathrm{a}^{*}, \mathrm{~b}^{*}$ of the left PM and IT muscles were measured using a Miniscan spectrocolorimeter (Hunterlab, 


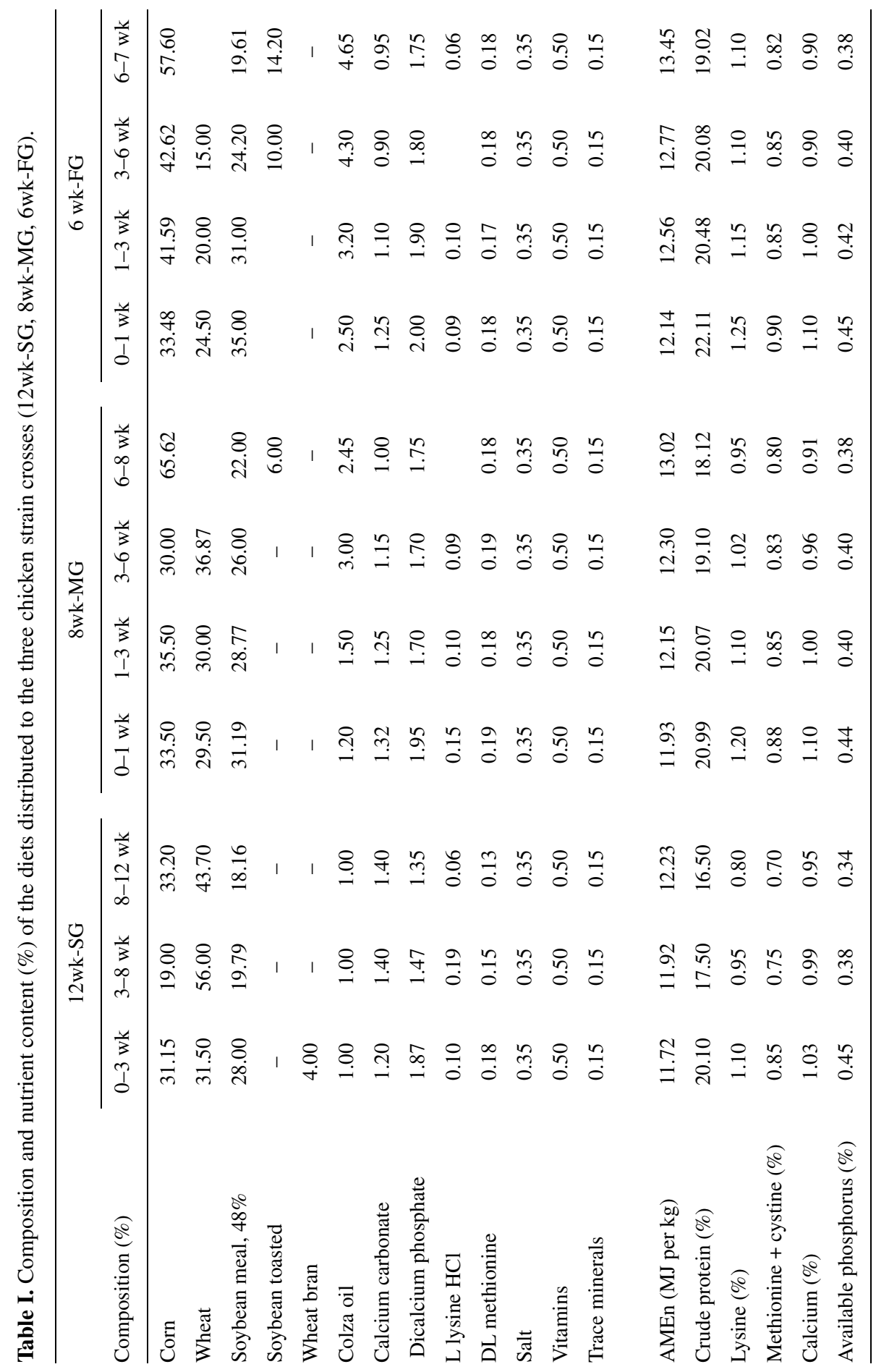


Reston, VA 20190). The colour measurements were performed on the ventral side of the cranial third of the PM muscle and on the central part of the external face of the IT muscle of the thigh.

\subsection{Meat processing and processed product analysis}

After thawing, the meat from the PM muscle $(n=64)$ and leg $(n=64)$ was respectively processed into white cured-cooked meat and ham. The breasts were manually lacerated and cured with brine containing $17.60 \%$ sodium nitrite, $7.67 \%$ dextrose, $2.20 \%$ carraghenan, and $0.33 \%$ sodium ascorbate (w:v). After boning and skin removal, the leg meat was also manually lacerated then cured by injection with brine containing $17.60 \%$ sodium nitrite, $9.90 \%$ dextrose, and $0.30 \%$ sodium ascorbate (w:v). Brine was injected at a ratio of $10 \%$ of the fresh meat weight. Both types of cured meat were vacuum tumbled at $4{ }^{\circ} \mathrm{C}$ : for $30 \mathrm{~min}$ at 7 rotations per min then for $10 \mathrm{~h}$ in alternating 5 minute tumbling at 7 rotations per min and 10 min stopping periods. Tumbled meats were vacuum-packed in $5 \mathrm{~kg}$-loaves, cooked until a core temperature of $66^{\circ} \mathrm{C}$ and cooled at $0{ }^{\circ} \mathrm{C}$ for $24 \mathrm{~h}$. Two days after the curingcooking process, the loaves (2 per strain cross) were cut into $2 \mathrm{~mm}$-thick slices, which were packaged under a $70 \%$ nitrogen and $30 \%$ carbon dioxide atmosphere until the analysis of chemical composition and sensory attributes.

Moisture, lipid, protein and total collagen contents were determined $3 \mathrm{~d}$ after processing according to the procedures NFV4401, ISO1444, NFV4407 and NFV4415 edited by AFNOR (Saint Denis La Plaine, France), respectively. The amount of protein free of collagen and lipid (PCL) was calculated using the following equation: PCL $(\%)=$ [(\% of proteins $-\%$ of collagen $) /(100-\%$ of lipids) $] \times 100$. Sensory evaluation of white cured-cooked meat and ham was performed according to the recommendations of AFNOR [1], $6 \mathrm{~d}$ after processing. Two sessions with 12 trained judges were organ- ised in parallel allowing 24 repeated analyses for each treatment. The sensory evaluation of the white cured-cooked meat and ham was performed separately. Panelists were asked to note the aspect, odour, taste and texture criteria on a scale from 1 (low score) to 7 (high score).

\subsection{Statistics}

A one-way analysis of variance was used to test the effect of the strain cross (6wk-FG, $8 \mathrm{wk}-\mathrm{MG}, 12 \mathrm{wk}-\mathrm{SG}$ ) per pen on growth performance and raw meat traits within meat type (breast or leg). Means were compared using a Newman-Keuls test for multiple mean comparison [27]. A one-way analysis of variance was used to test the effect of the strain cross (6wk-FG, 8wk-MG, 12wk-SG) on mean panel sensory attributes within meat type (breast or leg). Means were compared using the Paired Least Square Difference test of Fisher. The processing yields and the chemical composition of the resulting products are presented as raw data, since they were run on pooled samples.

\section{RESULTS}

\subsection{Carcass and muscle traits}

We observed differences (Tab. II) in slaughter weight and body composition among the three groups (6wk-FG, 8wkMG, 12wk-SG). At slaughter, the 12wk-SG were heavier but exhibited lower breast yield than the $6 w k-F G$ and $8 w k-M G$. The $6 w k-F G$ were the lightest at slaughter. All strain crosses exhibited the same breast weight. The $6 \mathrm{wk}-\mathrm{FG}$ exhibited the lowest and the $12 \mathrm{wk}-\mathrm{SG}$ the highest abdominal fat yield. The $8 \mathrm{wk}-\mathrm{MG}$ were intermediate between $6 \mathrm{wk}-\mathrm{FG}$ and $12 \mathrm{wk}-\mathrm{SG}$ chickens for slaughter weight, breast and abdominal fat yields. Leg yield did not differ among strain crosses.

Composition as well as fibre size of the PM muscle significantly differed among the 
Table II. Slaughter and breast weight (g) and carcass composition (\%) of the three chicken strain crosses ( $n=64=8$ pens of 8 birds).

\begin{tabular}{lccccc}
\hline Variables & 6 wk-FG & 8 wk-MG & 12 wk-SG & SEM & ANOVA \\
\hline Slaughter weight $(\mathrm{g})$ & $2496^{\mathrm{c}}$ & $2650^{\mathrm{b}}$ & $2877^{\mathrm{a}}$ & 16.25 & $* * *$ \\
Breast weight $(\mathrm{g})$ & 421 & 415 & 412 & 3.56 & NS \\
Breast yield (\%) & $16.9^{\mathrm{a}}$ & $15.6^{\mathrm{b}}$ & $14.3^{\mathrm{c}}$ & 0.13 & $* * *$ \\
Leg yield $\left.^{1} \%\right)$ & 24.3 & 24.5 & 24.8 & 0.15 & NS \\
Abdominal fat $(\%)$ & $2.60^{\mathrm{c}}$ & $3.20^{\mathrm{b}}$ & $3.56^{\mathrm{a}}$ & 0.07 & $* * *$ \\
\hline
\end{tabular}

$* * *: P \leq 0.001$; NS: non-significant.

1 Thigh + drumstick.

a, c Means within a row lacking a common superscripts differ $(P<0.05)$.

Table III. Chemical composition (\%) and fibre cross sectional area (CSA, $\left.\mu \mathrm{m}^{2}\right)$ of the Pectoralis major muscle of the three chicken strain crosses ( $\mathrm{n}=16=8$ pens of 2 birds).

\begin{tabular}{lccccc}
\hline Variables & $6 w k-F G$ & $8 w k-M G$ & $12 w k-S G$ & SEM & ANOVA \\
\hline Dry matter $(\%)$ & $24.95^{\mathrm{b}}$ & $25.35^{\mathrm{b}}$ & $26.29^{\mathrm{a}}$ & 0.193 & $* * *$ \\
Proteins $(\%)$ & $23.83^{\mathrm{b}}$ & $24.30^{\mathrm{ab}}$ & $24.66^{\mathrm{a}}$ & 0.190 & $* *$ \\
Lipids $(\%)$ & $1.25^{\mathrm{a}}$ & $1.01^{\mathrm{b}}$ & $1.18^{\mathrm{ab}}$ & 0.042 & $* *$ \\
Fibre CSA $\left(\mu \mathrm{m}^{2}\right)$ & $2168^{\mathrm{a}}$ & $1834^{\mathrm{ab}}$ & $1719^{\mathrm{b}}$ & 99.412 & $* * *$ \\
\hline
\end{tabular}

$* *: P \leq 0.01, * * *: P \leq 0.001$.

$\mathrm{a}, \mathrm{b}$ Means within a row lacking a common superscripts differ $(P<0.05)$.

chicken types (Tab. III). The PM muscle of the $12 \mathrm{wk}-\mathrm{SG}$ exhibited the highest dry matter and higher protein than the $6 \mathrm{wk}-\mathrm{FG}$. The 8 wk-MG PM muscle had the lowest lipid content. The PM muscle of the $12 \mathrm{wk}-\mathrm{SG}$ contained fibres with lower cross sectional area than those of the $6 \mathrm{wk}-\mathrm{FG}$. Fibres of the 8 wk-MG PM muscle were intermediate for this trait.

\subsection{Post mortem changes in muscle pH and raw meat traits}

$\mathrm{pH}_{15}$ and $\mathrm{pH}_{\mathrm{u}}$ as well as the colour and drip loss of the PM and IT muscles were affected by strain cross (Tab. IV). The PM muscle of the $12 \mathrm{wk}-\mathrm{SG}$ exhibited the lowest $\mathrm{pH}_{15}, \mathrm{pH}_{\mathrm{u}}$ and lightness values and the highest redness. It also exhibited higher drip loss than the 6wk-SG PM muscle. The 6wkFG PM muscle showed the highest values of $\mathrm{pH}_{15}$ and $\mathrm{pH}_{\mathrm{u}}$ and the lowest drip loss. The PM muscle redness and lightness were similar in the 6wk-FG and 8wk-MG. As for the PM muscle, the IT muscle of the $12 \mathrm{wk}-$ SG exhibited lower $\mathrm{pH}_{15}$ and $\mathrm{pH}_{\mathrm{u}}$ than those of the $8 \mathrm{wk}-\mathrm{MG}$ and $6 \mathrm{wk}-\mathrm{FG}$. The 12wk-SG and 8wk-MG IT muscles exhibited lower redness and drip loss than the 6wk-FG.

The relationships between the breast $\mathrm{pH}$ and meat traits were different according to the strain crosses (Tab. V). In 8wk-MG and $12 \mathrm{wk}-\mathrm{SG}$, breast lightness was positively related to $\mathrm{pH}_{15}$ and negatively to $\mathrm{pH}_{\mathrm{u}}$ while in the 6wk-FG, it was only negatively related to breast $\mathrm{pH}_{\mathrm{u}}$. Breast drip loss was negatively related to both $\mathrm{pH}_{15}$ and $\mathrm{pH}_{\mathrm{u}}$ in the $12 \mathrm{wk}-\mathrm{SG}$ but only to $\mathrm{pH}_{15}$ in the $6 \mathrm{wk}-$ FG and $\mathrm{pH}_{\mathrm{u}}$ in the 8 wk-MG. $\mathrm{pH}_{\mathrm{u}}$ was negatively related to breast yellowness for all strain crosses. It was also negatively related to the redness of the $6 \mathrm{wk}-\mathrm{FG}$ breast, that of the $8 \mathrm{wk}-\mathrm{MG}$ and $12 \mathrm{wk}-\mathrm{SG}$ breasts being only negatively related to $\mathrm{pH}_{15}$. 
Table IV. $\mathrm{pH}$ and colour parameters of the Pectoralis major (PM) and Ilio tibialis (IT) muscles and drip loss of PM and leg of the three chicken strain crosses ( $n=64=8$ pens of 8 birds).

\begin{tabular}{lcccccc}
\hline Tissues & Variables & 6 wk-FG & $8 w k-M G$ & 12 wk-SG & SEM & ANOVA \\
\hline PM & $\mathrm{pH}_{15}$ & $6.67^{\mathrm{a}}$ & $6.55^{\mathrm{b}}$ & $6.22^{\mathrm{c}}$ & 0.018 & $* * *$ \\
& $\mathrm{pH}_{\mathrm{u}}$ & $6.03^{\mathrm{a}}$ & $5.78^{\mathrm{b}}$ & $5.66^{\mathrm{c}}$ & 0.012 & $* * *$ \\
& $\mathrm{~L}^{*}$ & $52.57^{\mathrm{a}}$ & $52.85^{\mathrm{a}}$ & $50.75^{\mathrm{b}}$ & 0.255 & $* * *$ \\
& $\mathrm{a}^{*}$ & $-0.36^{\mathrm{b}}$ & $-0.03^{\mathrm{b}}$ & $0.43^{\mathrm{a}}$ & 0.136 & $* * *$ \\
& $\mathrm{~b}^{*}$ & 9.15 & 9.18 & 8.51 & 0.229 & $\mathrm{NS}$ \\
& Drip loss $(\%)$ & $1.24^{\mathrm{b}}$ & $1.46^{\mathrm{ab}}$ & $1.64^{\mathrm{a}}$ & 0.103 & $* * *$ \\
$\mathrm{IT}$ & & & & & \\
& $\mathrm{pH}_{15}$ & $6.58^{\mathrm{a}}$ & $6.59^{\mathrm{a}}$ & $6.31^{\mathrm{b}}$ & 0.012 & $* * *$ \\
& $\mathrm{pH}_{\mathrm{u}}$ & $6.43^{\mathrm{a}}$ & $6.36^{\mathrm{b}}$ & $6.15^{\mathrm{c}}$ & 0.018 & $* * *$ \\
& $\mathrm{~L}^{*}$ & 49.71 & 50.65 & 49.30 & 0.497 & NS \\
& $\mathrm{a}^{*}$ & $2.09^{\mathrm{a}}$ & $1.29^{\mathrm{b}}$ & $1.13^{\mathrm{b}}$ & 0.172 & $* * *$ \\
& $\mathrm{~b}^{*}$ & $7.06^{\mathrm{a}}$ & $6.93^{\mathrm{a}}$ & $4.01^{\mathrm{b}}$ & 0.362 & $* * *$ \\
& & & & & \\
Leg ${ }^{2}$ & Drip loss $(\%)$ & $0.50^{\mathrm{a}}$ & $0.33^{\mathrm{b}}$ & $0.36^{\mathrm{b}}$ & 0.019 & $* * *$ \\
\hline
\end{tabular}

$* *: P \leq 0.01 ; * * *: P \leq 0.001$; NS: non-significant.

1 Thigh + drumstick.

${ }^{\mathrm{a}, \mathrm{c}}$ Means within a row lacking common superscripts differ $(P<0.05)$.

Table V. Correlations between $\mathrm{pH}$ at $15 \mathrm{~min}$ or $24 \mathrm{~h}$ post mortem and colour and drip loss of Pectoralis major muscle within the three chicken strain crosses.

\begin{tabular}{lccc}
\hline & 6wk-FG & 8wk-MG & 12wk-SG \\
\hline $\mathrm{pH}_{15} / \mathrm{L}^{*}$ & $\mathrm{NS}$ & 0.40 & 0.28 \\
$\mathrm{pH}_{15} / \mathrm{a}^{*}$ & $\mathrm{NS}$ & -0.32 & -0.46 \\
$\mathrm{pH}_{15} / \mathrm{b}^{*}$ & $\mathrm{NS}$ & $\mathrm{NS}$ & $\mathrm{NS}$ \\
$\mathrm{pH}_{15} /$ drip loss & -0.32 & $\mathrm{NS}$ & -0.29 \\
$\mathrm{pH}_{\mathrm{u}} / \mathrm{L}^{*}$ & -0.29 & -0.61 & -0.34 \\
$\mathrm{pH}_{\mathrm{u}} / \mathrm{a}^{*}$ & -0.26 & $\mathrm{NS}$ & $\mathrm{NS}$ \\
$\mathrm{pH}_{\mathrm{u}} / \mathrm{b}^{*}$ & -0.25 & -0.30 & -0.30 \\
$\mathrm{pH}_{\mathrm{u}} / \mathrm{drip}$ loss & $\mathrm{NS}$ & -0.38 & -0.48 \\
\hline
\end{tabular}

\subsection{Technological yields and quality of processed products}

The processing yields of breast and leg meat were affected by the strain cross (Tab. VI). The breast and leg meat of the 12 wk-SG exhibited the lowest curing- cooking yields when processed in white cured-cooked meat and ham, respectively. Also, the processed products from the $12 \mathrm{wk}-\mathrm{SG}$ contained the highest dry matter and PCL (Protein free of Collagen and Lipid) contents. The highest curing-cooking yields were observed for breast and leg meat from the $6 \mathrm{wk}-\mathrm{FG}$. The processed products from the $6 \mathrm{wk}-\mathrm{FG}$ generally exhibited the lowest dry matter and PCL contents. Breast and leg meat from the 8wk-MG showed intermediate curing-cooking yields. Their white cured-cooked meat contained similar dry matter and PCL amounts as the 6 wk-FG while their hams were intermediate between $6 \mathrm{wk}-\mathrm{FG}$ and $12 \mathrm{wk}-\mathrm{SG}$ for these traits.

The white cured-cooked meat from 12 wk-SG showed a significantly less humid aspect and a drier texture than that of the 6 wk-FG (Fig. 1). It was also pinker than that of the $8 \mathrm{wk}-\mathrm{MG}$ products and had the best slice cohesiveness. The hams from the $12 \mathrm{wk}-\mathrm{SG}$ were darker and pinker than those from the other strain crosses and exhibited 
Table VI. Processing yields (\%) of the breast and leg meat and chemical composition (\%) of the white cured-cooked meat and ham from the three chicken strain crosses ( $\mathrm{n}=2$ loaves).

\begin{tabular}{lcccc}
\hline Tissues & Variables & 6wk-FG & 8wk-MG & 12wk-SG \\
\hline Breast & Thawing yield (\%) & 97 & 95.8 & 95.9 \\
& Cooking yield (\%) & 97.1 & 94.3 & 90.9 \\
& Curing-cooking yield (\%) & 106.8 & 103.8 & 100.0 \\
White cured-cooked meat & & & & \\
& Dry matter (\%) & 26.1 & 26.4 & 27.2 \\
& PCL $^{1}(\%)$ & 21.9 & 21.8 & 22.4 \\
& Lipid (\%) & 1.4 & 1.3 & 1.5 \\
& Collagen (\%) & 0.56 & 0.65 & 0.59 \\
Leg & & & & \\
& & 97.3 & 98.2 & 97.9 \\
& Thawing yield (\%) & 95.0 & 91.6 & 89.5 \\
& Cooking yield (\%) & 104.5 & 100.8 & 98.4 \\
Chicken Ham & Curing-cooking yield (\%) & & & \\
& & 26.1 & 27.5 & 27.7 \\
& Dry matter (\%) & 17.4 & 18.2 & 19.6 \\
& PCL $(\%)$ & 5.8 & 6.3 & 5 \\
& Lipid (\%) & 1.36 & 1.37 \\
\hline
\end{tabular}

${ }^{1}$ Protein free of Collagen and Lipid.

${ }^{2}$ Thigh + drumstick.

a less humid aspect than those from the 6wk-FG hams. There was no significant difference in taste and odour among the treatments for the 3 types of processed products (data not shown).

\section{DISCUSSION}

As expected, the $8 \mathrm{wk}-\mathrm{MG}$ were intermediate between the $12 \mathrm{wk}-\mathrm{SG}$ and $6 \mathrm{wk}-\mathrm{FG}$ for slaughter weight, breast yield, and abdominal fatness, which are major criteria for the breeding of broilers and are highly heritable traits [17]. The dry matter and protein contents of muscle increased with the slaughter age of the birds as already observed in chickens $[14,30]$. By contrast, muscle lipids were not clearly related to chicken age nor to growth performance since the PM muscle of $8 \mathrm{wk}-\mathrm{MG}$ exhibited lower lipid contents than those of both $6 \mathrm{wk}$ -
FG and 12 wk-SG. From the above results, it appears that both the structure and the composition of breast muscle are affected by the strain. Indeed, in fast-growing chickens that are slaughtered at a younger age, the fibre diameter of the breast muscle was significantly higher while its dry matter and protein contents were lower than in slowgrowing birds, medium-growing birds being generally intermediate for these traits.

We reported great differences of $\mathrm{pH}_{15}$ in both the PM and IT muscles among chickens strains. Indeed, the lowest $\mathrm{pH}_{15}$ values were observed in the muscles of $12 \mathrm{wk}-\mathrm{SG}$ and the highest in those of 6wk-SG. This was consistent with previous observations, which also showed a faster initial rate of $\mathrm{pH}$ fall in the breasts of 12 week-old 'labeltype' chickens than in the breasts of 6 or 8 week-old 'standard-type' chickens [7, 8]. By measuring the behaviour of birds before stunning, Debut et al. [8] pointed out that 

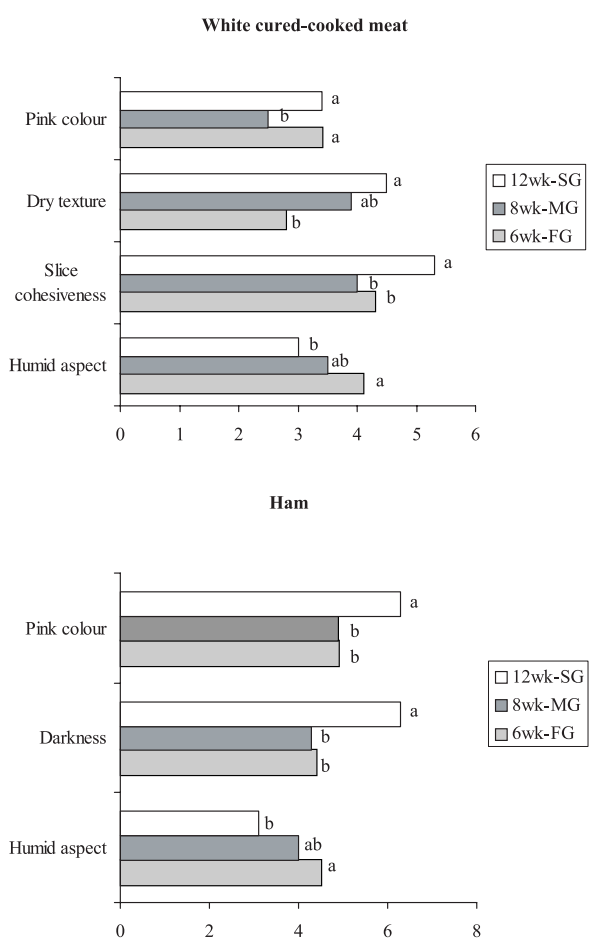

Figure 1. Effect of strain cross on the sensory attributes of the white cured-cooked meat and ham. The sensory evaluation of the white cured-cooked meat and ham were separately performed. Panel judges must note aspect, odour, taste and texture criteria from 1 (low) to 7 (high). $\mathrm{FG}=$ fast growing birds, $\mathrm{MG}=$ medium growing birds, $\mathrm{SG}=$ slow growing birds.

a, b: Means lacking common letters differ significantly at $P \leq 0.05$.

'label-type' slow-growing birds exhibit higher levels of struggling on the shackle line, resulting in a more rapid $\mathrm{pH}$ fall and an increase in redness of breast muscle. Also, we reported significantly lower ultimate $\mathrm{pH}$ in PM and IT muscles of $12 \mathrm{wk}-\mathrm{SG}$ compared to the two other strain crosses. A comparison at 6 weeks of broiler lines improved or not for body weight and/or breast yield has already suggested that increasing growth rate and/or muscle development could slow down the post mortem glycolysis and increase ultimate $\mathrm{pH}$ by lowering the glycogen content of the breast muscle [6]. Henckel [16] stated that a concentrated growth period of broilers may imply in muscle a constant state of hypoxia, obliging the use of the glycolytic pathway with degradation of glycogen to lactate in order to supply energy to the muscle cell, even for light activity. However, in the present study, since the three chicken crosses used were fed under various diets, reared under different stocking densities and slaughtered at different ages, we cannot exclude an additional effect of these factors on muscle metabolism and composition.

Our study pointed out that in all strains, breast drip loss was partly related to muscle $\mathrm{pH}$ either at $15 \mathrm{~min}$ or $24 \mathrm{~h}$ post mortem or both. This finding was consistent with previous results on broilers $[5,19]$ that reported high negative correlation between breast $\mathrm{pH}_{\mathrm{u}}$ and drip loss. The lack of a correlation between breast ultimate $\mathrm{pH}$ and drip loss in $6 \mathrm{wk}-\mathrm{FG}$ is likely due to the high $\mathrm{pH}$ values recorded in this group at $24 \mathrm{~h}$ post mortem. In $8 \mathrm{wk}-\mathrm{MG}$ and $12 \mathrm{wk}-\mathrm{SG}$, the redness and darkness of the breast muscle increased as its $\mathrm{pH}_{15}$ decreased. The negative correlation between $\mathrm{pH}_{15}$ and redness has already been reported in turkey $[10,13,15,23]$ and chicken [8] breast meat. A rapid $\mathrm{pH}$ fall after slaughter would be related to struggle before death and the higher redness would be due to the increased blood flow in breast muscle resulting from wing flapping $[8$, 13]. As mentioned above [8], slow growing chickens struggled more on the shackle line than fast growing broilers, which could explain that $\mathrm{pH}_{15}$ is correlated to the breast redness only in 8wk-MG and 12wk-SG. More generally, the pigment content of muscle could be related to the slaughter age and level of physical activity of the birds during rearing. Therefore, the relationship between $\mathrm{pH}_{15}$ and redness could be indirectly explained by the different slaughter ages, stocking densities and genetic behaviour of the birds belonging to the three 
groups. As already described in many studies on broilers $[2,5,11,19]$ and turkeys $[4$, $21,25]$, we also report a negative relationship between $\mathrm{pH}_{\mathrm{u}}$ and the lightness and yellowness of breast meat for all strain crosses.

We observed great variability in curingcooking yields of broiler meat among strain crosses. Obviously, the highest curingcooking yields were obtained for the meat with the highest values of $\mathrm{pH}_{15}$ and $\mathrm{pH}_{\mathrm{u}}$ (belonging to the 6wk-FG group). By contrast, the meat from the $12 \mathrm{wk}-\mathrm{SG}$, which exhibited the lowest values of $\mathrm{pH}_{15}$ and $\mathrm{pH}_{\mathrm{u}}$, had the lowest curing-cooking yields. The observed relationships between the meat $\mathrm{pH}$, either at $15 \mathrm{~min}$ or $24 \mathrm{~h}$ post mortem, and its processing yield are in accordance with the lower water binding ability of muscle protein when either the $\mathrm{pH}_{15}$ or the $\mathrm{pH}_{\mathrm{u}}$ or both are low [24]. The processed meat of $12 \mathrm{wk}-\mathrm{SG}$, which had the lowest curing-cooking yield, obviously exhibited the greatest dry matter and protein amounts and the driest aspect. The white curedcooked meat of $12 \mathrm{wk}-\mathrm{SG}$ also exhibited a drier texture and a better slice cohesiveness than that of the other strain crosses. Moreover, the $12 \mathrm{wk}-\mathrm{SG}$ processed meat exhibited a pinker colour, which was consistent with its higher redness before processing. From our observations, we cannot conclude whether the curing-cooking yield of broiler meat was chiefly determined by the meat $\mathrm{pH}_{15}$ or $\mathrm{pH}_{\mathrm{u}}$ or both. Recently, Fernandez et al. [10] reported that turkey meat with low $\mathrm{pH}$ at 20 min post mortem exhibited lower curing-cooking yield than meat with a higher $\mathrm{pH}$ value. However, the authors could not fully rule out a concomitant effect of $\mathrm{pH}_{\mathrm{u}}$ in determining processing yields. According to Offer [24], the fraction of denatured protein in pig muscle increases as the final $\mathrm{pH}$ decreases, particularly at high rates of $\mathrm{pH}$ fall, suggesting an additive effect of rate and extent of $\mathrm{pH}$ fall on muscle protein functionality. Even if our results confirmed the important role of muscle $\mathrm{pH}$ in determining meat processing ability they did not exclude that other muscle traits could be involved. Indeed, the collagen heat-solubility which is known to decrease as the broiler grows [22,31,32] or the fibre diameter that we showed here to differ significantly between strain crosses might be involved in the water holding ability of meat during cooking.

\section{CONCLUSION}

The technological traits and processing ability of chicken meat are greatly related to chicken strain crosses. Meat from fastgrowing birds exhibited better technological yields than medium- or slow-growing chickens but processed products made from these last birds exhibited greater dry matter and protein and better slicing ability. These results should be taken into account if the meat from extensively reared chickens ('free range') or intermediate growing chickens ('certified-type') are intended for the processed product market. This study confirmed the significant contribution of $\mathrm{pH}_{15}$ and $\mathrm{pH}_{\mathrm{u}}$ in determining the water holding ability and colour of chicken meat and as a consequence the quality of further processed products. It also shows that breast meat from slow growing birds would be more sensitive to variations in post mortem muscle $\mathrm{pH}$ fall than meat from fast growing birds. However, other muscle traits may play a role in determining the processing ability of meat and therefore the importance of complementary approaches to assess the contribution of them may be underlined.

\section{ACKNOWLEDGEMENTS}

This study was carried out with financial support from Office National Interprofessionnel des Viandes, de l'Élevage et de l'Aviculture (OFIVAL). The authors would like to thank T. Bordeau for his valuable technical assistance, N. Millet and the technical staff of the Unité Expérimentale Avicole for careful rearing of chickens. We also thank Hubbard-ISA for providing us chicken crosses. 


\section{REFERENCES}

[1] AFNOR, Contrôle de la qualité des produits alimentaires - Analyse Sensorielle, AFNOR (Ed.), 5th ed., 1995.

[2] Allen C.D., Russell S.M., Fletcher D.L., The relationship of broiler breast meat color and $\mathrm{pH}$ to shelf-life and color development, Poultry Sci. 76 (1997) 1042-1046.

[3] AOAC, Official Methods for Analysis, 14th ed., Association of Official Analytical Chemists, Arlington, VA, 1984.

[4] Barbut S., Colour measurements for evaluating the pale soft exudative PSE occurrence in turkey meat, Food Res. Int. 26 (1993) 39-43.

[5] Barbut S., Problem of pale soft exudative meat in broiler chickens, Brit. Poultry Sci. 38 (1997) 355-358.

[6] Berri C., Wacrenier N., Millet N., Le BihanDuval E., Effect of selection for improved body composition on muscle and meat characteristics of broilers from experimental and commercial lines, Poultry Sci. 80 (2001) 833838.

[7] Culioli J., Touraille C., Bordes P., Girard J.P., Carcass and meat characteristics of "label fermier" chickens, Arch. Geflügelk. 53 (1990) 237-245.

[8] Debut M., Berri C., Baéza E., Sellier N., Arnould C., Guémené D., Jehl N., Boutten B., Jego Y., Beaumont C., Le Bihan-Duval E., Variation of chicken meat quality in relation to genotype and stressing pre-slaughter conditions, Poultry Sci. 82 (2003) 1829-1838.

[9] Farmer L.J., Perry G.C., Lewis P.D., Nute G.R., Piggot J.R., Patterson R.L.S., Responses of two genotypes of chickens to the diets and stocking densities of conventional UK and Label Rouge production systems: II. Sensory attributes, Meat Sci. 47 (1997) $77-$ 93.

[10] Fernandez X., Santé V., Baéza E., Le BihanDuval E., Berri C., Rémignon H., Babilé R., Le Pottier G., Astruc T., Effects of the rate of postmortem $\mathrm{pH}$ fall on the processing ability of turkey meat, Brit. Poultry Sci. 43 (2002) 245-252.

[11] Fletcher D.L., Broiler breast meat color variation, $\mathrm{pH}$, and texture, Poultry Sci. 78 (1999) $1323-1327$

[12] Folch J., Lees M., Sloane Stanley G.H., A simple method for the isolation and purification of total lipids from animal tissues, J. Biol. Chem. 226 (1957) 497-509.

[13] Froning G.W., Babji A.S., Mather F.B., The effect of preslaughter temperature, stress, struggle and anesthetization on color and textural characteristics of turkey muscle, Poultry Sci. 57 (1978) 630-633.

[14] Grey T.C., Robinson D., Jones J.M., Stock S.W., Thomas N.L., Effect of age and sex on the composition of muscle and skin from a commercial broiler strain, Brit. Poultry Sci. 24 (1983) 219-231.

[15] Hahn G., Malenica M., Müller W.D., Taubert E., Petrak T., Influence of postmortal glycolysis on meat quality and technological properties of turkey breast, in: Proceedings of the 15th European Symposium on the Quality of Poultry Meat, Kusadasi, Turkey, 2001, pp. 325-328.

[16] Henckel P., Physiology and biochemistry of muscle fibres in poultry, in: Proceedings of the 2nd European Poultry Breeders Roundtable, Foulum, Denmark, 1996, pp. 79-89.

[17] Le Bihan-Duval E., Mignon-Grasteau S., Millet N., Beaumont C., Genetic analysis of a selection experiment on increased body weight and breast muscle weight as well as on limited abdominal fat weight, Brit. Poultry Sci. 39 (1998) 346-353.

[18] Le Bihan-Duval E., Millet N., Rémignon H., Broiler meat quality: effect of selection for increased carcass quality and estimates of genetic parameters, Poultry Sci. 78 (1999) 822-826.

[19] Le Bihan-Duval E., Berri C., Baéza E., Millet N., Beaumont C., Estimation of the genetic parameters of meat characteristics and of their genetic correlations with growth and body composition in an experimental broiler line, Poultry Sci. 80 (2001) 839-843.

[20] Magdelaine P., Introduction sur la conjoncture volailles de chair et la place des volailles sous signes officiels de qualité, in: Proceedings of the Journée Volailles sous Signes Officiels de Qualité, Angers, France, 2004.

[21] McCurdy M.C., Barbut S., Quinton M., Seasonal effects on PSE in young turkey breast meat, Food Res. Int. 29 (1996) 363-366.

[22] Nakamura R., Sekoguchi S., Sato Y., The contribution of intramuscular collagen to the tenderness of meat from chickens with different ages, Poultry Sci. 54 (1975) 1604-1612.

[23] Ngoka D.A., Froning G.W., Lowry S.R., Babji A.S., Effects of sex, age, preslaughter factors, and holding conditions on the quality characteristics and chemical composition of turkey breast muscles, Poultry Sci. 61 (1982) 1996-2003.

[24] Offer G., Modelling of the formation of pale, soft and exudative meat: Effects of chilling 
regime and rate and extent of glycolysis, Meat Sci. 30 (1991) 157-184.

[25] Rathgeber B.M., Boles J.A., Shand P.J., Rapid postmortem $\mathrm{pH}$ decline and delayed chilling reduce quality of turkey breast meat, Poultry Sci. 78 (1999) 477-484.

[26] Rémignon H., Gardahaut M.F., Marché G., Ricard F.H., Selection for rapid growth increases the number and the size of muscle fibres without changing their typing in chickens, J. Muscle Res. Cell Motil. 16 (1995) 95102.

[27] SAS Institute, SAS User's Guide: Statistics, SAS Institute Inc., Cary, NC, 1989.

[28] Santé V., Fernandez X., The measurement of $\mathrm{pH}$ in raw and frozen turkey Pectoralis superficialis muscle, Meat Sci. 55 (2000) 503-506.
[29] Sauveur B., Les critères et facteurs de la qualité des poulets Label rouge, INRA Prod. Anim. 10 (1997) 219-226.

[30] Singh S.P., Essary E.O., Factors influencing dressing percentage and tissue composition of broilers, Poultry Sci. 53 (1974) 2143-2147.

[31] Touraille C., Kopp J., Valin C., Ricard F.H., Chicken meat quality. 1. Influence of age and growth rate on physico-chemical and sensory characteristics of the meat, Arch. Geflügelk. 45 (1981) 69-76.

[32] Touraille C., Ricard F.H., Kopp J., Valin C., Leclerq B., Chicken meat quality. 2. Changes with age of some physico-chemical and sensory characteristics of the meat, Arch. Geflügelk. 45 (1981) 97-104. 